DOI 10.14746/ssp.2020.1.2

Stanisław WóJcik

Katolicki Uniwersytet Lubelski

ORCID: 0000-0003-0616-3604

\title{
Samorząd terytorialny w perspektywie personalizmu społecznego ${ }^{1}$
}

Streszczenie: $\mathrm{W}$ artykule zarysowano program naprawczy samorządu terytorialnego w oparciu o nowy prąd doktrynalny - personalizm społeczny. Wskazuje on nowe możliwości reformowania ustroju i funkcjonowania samorządu, postaw osobowych. Jest to nowa droga rozwoju społeczności lokalnych promująca idee i wiedzę humanistyczną, etyczną, próbuje skorygować dominujący nurt liberalizmu, który coraz bardziej podlega degeneracji.

Słowa kluczowe: człowiek, państwo, samorząd, personalizm społeczny

\section{Kryzys samorządności}

yjemy w czasach (III RP) osłabionej podmiotowości państwa, przeżywania się polskiej formy liberalno-demokratycznej, wstrząsanej kryzysami parlamentarnymi, rządowymi, partyjnymi. Państwo (parlament, rząd, wymiar sprawiedliwości, administracja, gospodarka) wymaga reform ustrojowych. Mamy również do czynienia z „walką kulturową” o tzw. nową, otwartą świadomość, kształtowaną przez postępowców ideowych, liberalnych i lewicowych, chcących pozbawić Polaków patriotyzmu i religijności.

Ważną rolę do odegrania może mieć zreformowany samorząd terytorialny, który powinien stać się miernikiem jakości państwa i społeczności lokalnej. Samorząd jest instytucją bardzo wszystkim potrzebną, doniosłą, ale jest skomplikowany w realizacji, bowiem kształtuje się nie tylko we

1 Personalizm społeczny to system dający powszechną koncepcję rzeczywistości, ukazujący uwarunkowania i możliwości aktywnego i odpowiedzialnego udziału człowieka jako osoby w życiu społecznym, kulturalnym, gospodarczym, politycznym, cywilizacyjnym. Oznacza to wyjście poza temat samej osoby. Tak ujęty personalizm staje się teorią całej rzeczywistości z punktem wyjścia w zjawisku osoby ludzkiej (Bartnik, 2000; Flewelling, 2004, s. 353-355; Wójcik, 2018, s. 717 i n.). 
współpracy, ale i w konflikcie z władzą państwową. Studia nad samorządem pozwalają dostrzec, że jest on koniecznym dopełnieniem władzy państwowej; spełnia rolę „ciśnienia obwodowego”, którego nie może spełnić państwo (Wójcik, 2013, s. 55; Wójcik, 2016, s. 151 i n.).

Za ten stan rzeczy, za nie dość konsekwentne realizowanie decentralizacji, za braki w systemie prawnym, a także stan finansów i gospodarki lokalnej odpowiada również nieokreślony system filozofii samorządu. Dzisiaj niemal wszyscy w Europie stawiają sobie pytanie ,jak żyć?” w tym naszym skomplikowanym świecie. Pesymiści nie znajdują pewnej odpowiedzi, zadowalając się konstatacją o zmierzchu Zachodu, a co bardziej radykalni postępowcy formułują jednostronne postulaty antycywilizacyjne. Warto jednak patrzeć zarówno w głąb historii, jak i trzeźwo spoglądać w przyszłość oraz zgodzić się z wyrażoną ostatnio przez Konrada Kołodziejskiego opinią o wciąż aktualnym znaczeniu dla ludzi cywilizacji łacińskiej, ale trzeba ją należycie rozumieć, wyraziście dookreślić $^{2}$. Jest ona trudna w realizacji, wymagająca wiele od człowieka i ludzi, ale niezmiennie ukazuje kierunek i potrzebę, jak utrzymać status człowieka w zmieniającej się rzeczywistości jako osoby godnej, podmiotowej - jest jednak realistyczna, i jak od 2000 lat pokazuje historia chrześcijaństwa, jest też uniwersalistyczna. W jej systemie wartości dominują godność, dobro człowieka i społeczeństwa, wolność, sprawiedliwość, równość. W cywilizacji tej chodzi o kształtowanie ludzi realnych, rozumnych i wolnych, budowniczych kultury i suwerennych w budowie swojego życia społecznego.

Jakie znaczenie może spełniać personalizm społeczny jako nowy chrześcijański kierunek teoretyczny, wyjaśniający rolę jednostek samorządu terytorialnego dla człowieka, społeczności lokalnych i państwa. Pierwsi nowożytni teoretycy samorządności widzieli w gminie wartość, która umożliwia obywatelom doskonalenie się, stawanie się społecznie twórczymi. Jednak współczesna praktyka i organizacja administracji lokalnej jeszcze w dużym stopniu jej nie potwierdza (Wójcik, 1999, s. 345). Samorząd miał sprzyjać formowaniu się podmiotowości obywatelskiej

${ }^{2}$ Cywilizacja łacińska, chrześcijaństwo całkowicie zmieniło status człowieka, nadało mu godność i podmiotowość... Chrześcijanie ujmując wszystko w ramy sprawiedliwości oraz moralności, wprawili świat zachodni w ruch i nadali mu cel. Cel zupełnie wykraczający poza codzienną egzystencję, cel doskonały, którym jest zbawienie każdego człowieka. Zmierzający do niego człowiek stał się centralnym punktem naszej cywilizacji i jej największą siłą (Kołodziejski, 2019 s. 76; por. Roszkowski, 2019). 
oraz rozwijać demokrację lokalną jako podstawę demokratyczną państwa i stawać się szkołą obywatelskiego wychowania. Do nich dołączano inne wartości cenne dla ludzi, jak sprawiedliwy, otwarty dostęp do władzy (jasne, zrozumiałe techniki wyborcze) i jej służebność wobec społeczności lokalnej, która odpłaca swej władzy lojalnością, że samorządy sprzyjają rozwojowi godności, reprezentatywności. Jednak współcześnie wciąż odczuwamy deficyt tych wartości. Ich występowanie zależy zarówno od jakości środowiska społecznego, jak i politycznego (władzy państwowej). Wolność obywatelska i demokracja lokalna zależą od przyznanego zakresu decentralizacji, wspomaganej przez wszystkie zasady personalizmu społecznego: godność osoby ludzkiej, dobro wspólne, pomocniczość, solidarność, sprawiedliwość, jak i poczucie suwerenności narodu. Te zasady współżycia społecznego częściowo mają konkretyzację w prawie, ale zagrażają im tendencje płynące od władzy państwowej: centralizacja i recentralizacja. Natomiast siła działania tych zasad będzie zależeć od ludzi, którzy przyswoją sobie filozofię personalistyczną.

\section{Problem badawczy}

Celem artykułu jest ukazanie możliwości i rosnącego znaczenia personalizmu społecznego w analizie sposobów i treści społecznej funkcjonowania samorządu terytorialnego. Wprowadza on ład w stosunki międzyludzkie, w relacje osoba-osoby, ludzką komunikację opartą na najwyższych wartościach naszej cywilizacji. Te wartości osobowe kształtować także będą kierunki zadań i działań instytucji społeczno-politycznych (Wójcik, 2018, s. 11).

Główny problem badawczy to ukazanie perspektywy samorządności w Polsce, przez określenie czym staje się samorząd terytorialny w świetle aksjologii. Tezy są następujące: mamy do czynienia z kryzysem samorządności; samorząd terytorialny nie może być oderwany od kluczowych wartości: podmiotowości obywatelskiej, od obywatelskiego wychowywania społeczności lokalnej, od demokracji lokalnej - bo na nich go zbudowano; dzisiaj u podstaw samorządu terytorialnego jest słaba warstwa chrześcijańska; szerokie uznanie zdobył natomiast liberalizm, który niesie pewne wartości, ale też jest postrzegany jako wielkie zagrożenie: samorządy bazują na niskim poziomie moralnym i prawnym władz, a społeczności lokalne nie posiadają wystarczającego doświadczenia społecznego do samorządności (kultury politycznej, postaw obywatelskich); 
istnieje konieczność przeformowania samorządu terytorialnego w duchu personalizmu społecznego.

\section{Samorząd w świetle personalizmu społecznego}

Do wykorzystania przez samorząd w najbliższym czasie winno stać się stanowisko personalizmu społecznego - jako systemu, dzisiaj wciąż mało znane, ale bardzo ważne. W katolickiej nauce społecznej źródłem zasad niezbędnych dla właściwego funkcjonowania społeczeństwa jest personalizm społeczny. Uznaje on zasadę wrodzonej godności osoby ludzkiej, to znaczy, że osobę ludzką należy szanować, afirmować dla niej samej, bo jest osobą. Społeczeństwo istnieje dla niej i dzięki niej. Oznacza to, że z jednej strony społeczeństwo istnieje dla człowieka jako osoby, ale $\mathrm{z}$ drugiej, człowiek jako jednostka wtórnie istnieje też dla społeczności. Społeczność służy człowiekowi jako jednostce, a człowiek jako jednostka służy społeczności. Tę personalistyczną relację dobrze oddaje elipsa, krzywa płaska zamknięta, która ma dwa połączone centra ${ }^{3}$.

Godność osoby ludzkiej domaga się budowy życia społecznego w oparciu o zasady dobra wspólnego, pomocniczości, solidarności i sprawiedliwości. Zasady te porządkują dany system społeczny na miarę człowieka jako osoby, gdyż umożliwiają stworzenie takich struktur, w których osoba ma zapewnione poszanowanie swej godności i posiada szansę pełnego, integralnego rozwoju. W tym ujęciu człowiek jako osoba odnoszony jest do całego życia społecznego, szczególnie lokalnego. Oznacza to wyjście poza problematykę osoby jako bytu indywidualnego (personalizm antropologiczny). Personalizm jako system ukazuje sposób związania osoby z innymi osobami w społeczność - kolektyw, wskazując kierunek w rozwiązywaniu kwestii społecznej (Bartnik, 2006, s. 11; Mazurek, 2001, s. 17 i n., 133 i in., s. 150 i n.; Wójcik, 2015, s. 49-50).

Personalizm zwraca przy tym uwagę na ochronę podmiotowości każdego z nas mówiąc, że jest to podstawowy wymóg racjonalności wszelkich działań społecznych, zdrowej struktury społeczeństwa i zasad jej funkcjonowania. Możemy więc mówić o kreowaniu zasady autonomii dla lokalnych społeczności. Samorząd ma być gospodarzem na swoim terenie, ale jego autonomia może mieć tylko charakter lokalny i względ-

${ }^{3} \mathrm{~W}$ marksizmie i liberalizmie występuje brak tego łączenia, tj. prawa społecznego. 
ny. Należy w tym miejscu przypomnieć i podkreślić opinię pochodzącą od samorządowców z 20-lecia międzywojennego, że zakres uprawnień przyznanych samorządowi przez państwo powinien być zależny od dojrzałości politycznej społeczeństwa. Kontrola i nadzór państwa nad samorządem musi być tym bardziej ścisła i wnikliwa, im młodsza jest organizacja samorządu, im niższa kultura społeczna. Nie może jednak posunąć się zbyt daleko, gdyż doprowadziłaby do odebrania inicjatywy, śmiałości samodzielnych poczynań, sprowadziła stagnację i marazm. Chodzi o delikatną równowagę relacji nadzoru prawnego państwa i celowej działalności samorządu terytorialnego, by miał on swobodę w wyrażaniu swych celów, programów i sposobów działania, by mógł dysponować własnymi środkami materialnymi i finansowymi i powoływał swe władze niezależnie i samodzielnie. Samorząd terytorialny staje się wtedy jednym z wielu składników pluralizmu państwowego. Spośród mnóstwa społeczności pośrednich jest najbliższy państwu swą kulturą i charakterem. Jego istotnymi składnikami, tak jak i państwa, są ludzie, terytorium i władza. Ma wspólne zasadnicze cechy z państwem: łączy ogół mieszkańców danego terytorium, co nadaje mu charakter powszechności, zaś jego celem jest dobro wspólne ludności zamieszkałej na jego terytorium, co przydaje mu cechę wszechstronności oraz posiada władzę, która może domagać się posłuszeństwa.

Podstawową wartością samorządu jest wspólnota osób żyjąca dla dobra wspólnego i dla dobra osób jednocześnie. Dlatego samorząd określa się bądź jako szczególny związek osób stale zamieszkałych na określonym obszarze (ujęcie podmiotowe), bądź prawnie wyodrębnioną jednostkę podziału terytorialnego, z zamieszkałą na niej ludnością (ujęcie przedmiotowe). Samorząd terytorialny reprezentuje interesy społeczności lokalnych i posiada ustawowo określony stopień autonomii, będąc integralną częścią państwa (Skorowski, 1966, s. 174).

Pytania czym jest i dlaczego potrzebny jest samorząd terytorialny stawiało sobie wielu wybitnych ludzi Kościoła. Z ich wypowiedzi i opinii wynika, że samorząd terytorialny jest jedną z podstawowych instytucji uczestnictwa obywateli w życiu społecznym, i - jak zauważa Andrzej Sujka - głównym obszarem ich odpowiedzialności i aktywności oraz troski o dobro wspólne, i dodajmy, że potępiali wszelką prywatę urzędniczą. Na Soborze Watykańskim II zapisano, że dobro wspólne stanowi sumę warunków życia społecznego, jakie zrzeszeniom, bądź poszczególnym członkom społeczeństwa pozwalają osiągnąć pełniej i łatwiej własną doskonałość (Sujka, 1998, s. 13). Dobrze zorganizowany i prawidłowo 
funkcjonujący samorząd terytorialny, nastawiony na realizację dobra wspólnego, jest instytucją kształtującą realne obywatelstwo i podmiotowość każdego z nas, w tym również rozwój, pełną aktualizację i modernizację życia społecznego, humanizację w oparciu o najlepsze teorie społeczno-polityczne. W sumie winien przyczyniać się do wzbogacania społeczności lokalnych w aspekcie gospodarczym, socjalnym i kulturalnym. Samorząd terytorialny może lepiej niż instytucja państwowa odczytywać i czuć potrzeby i zadania swojej wspólnoty i władzy w ogóle, a tym samym przyczyniać się do dynamicznego rozwoju kapitału społecznego, jak i państwowego. Ponadto, może stanowić szczególne medium między życiem indywidualnym i zbiorowym.

Celem samorządu terytorialnego jest zaspokajanie potrzeb lokalnych oraz kształtowanie ładu i pokoju społecznego (dobro wspólne) na terenie gmin, powiatów i regionów. Ład i pokój społeczny wymagają, aby zakres kompetencji i zadań samorządów poszczególnych stopni był różny, żeby każdy z nich realizował dobro wspólne we własnym zakresie. Chodzi przy tym o to, żeby ich prawa i obowiązki nie wchodziły w kolizję, żeby władze umiały podjąć współpracę, sprzyjać stabilizacji społecznej, wychowaniu obywatelskiemu i coraz wyższej jakości funkcjonowania administracji samorządowej.

Dobre funkcjonowanie samorządów wymaga oparcia życia społecznego na wspomnianych wyżej zasadach. Oprócz zasady dobra wspólnego, kluczowe znaczenie ma zasada pomocniczości. Wywodzi się ona z założenia, że osoba ludzka jest źródłem, podmiotem i celem dynamicznej rzeczywistości społecznej. Wszelkie instytucje powinny być tworzone jako pomocnicze w stosunku do jej działań. Zasada ta odnosi się zwłaszcza do relacji państwo-samorząd. Państwo ma sprzyjać autonomii i jedynie wspierać obywatela i organizacje społeczne. Pomocniczość wymaga podziału władzy, kompetencji i środków materialnych pomiędzy państwem a zorganizowanym społeczeństwem. Wymaga to odpowiedniej decentralizacji w szeregu dziedzinach społeczno-gospodarczo-administracyjnych. W toku tego procesu wyłaniać się będzie personalistyczny ustrój państwa oparty na dualizmie administracyjnym, na ograniczonej autonomii władzy (Majka, 1982, s. 165; Wójcik 2002, s. 114-115).

Zasada pomocniczości jest wielowymiarowa. Jako zasada ontologiczna wskazuje, że dobro wspólne jest dla osoby, która jest bytem względnie absolutnym, bo jednocześnie człowiek jako jednostka jest dla społeczności. Tak więc osoba ludzka i jej dobro jest podstawowym celem społeczności. Jak stwierdza Czesław Skrzeszewski, z faktu, że osoba ludzka 
jest ostatecznym podmiotem i celem życia społecznego wynika, że zaspokojenie potrzeb ludzkich wyznacza charakter społeczności i zakres jej uspołecznienia. Jeżeli mniejsza społeczność może zaspokoić potrzeby człowieka, to nie ma podstawy naturalnej do powstawania społeczności szerszej (Skrzeszewski, 1994, s. 517).

Pomocniczość ma również wymiar prawny i pozostaje w relacji do praw społecznych. Stąd każda społeczność mniejsza nie musi odwoływać się do społeczności większych, jeśli nie ma konieczności, a każda społeczność wyższa musi szanować prawo podmiotowe społeczności niższych (Skorowski, 1966, s. 176).

Zasada pomocniczości jest także zasadą moralną, to znaczy, że wiąże człowieka i społeczność w sumieniu co do przestrzegania obowiązków. Możemy zatem powiedzieć, że zasada pomocniczości ma na celu wspieranie procesu tworzenia wielostopniowych struktur społeczności, w których będzie poszanowanie człowieka jako osoby i wspólnot osobowych. A więc można ją uznać za zasadę o charakterze personalistycznym, gdyż jej treścią jest wskazanie konieczności, a jednocześnie granic wolności człowieka i mniejszych społeczności. Wskazuje, iż podstawą i uzasadnieniem wolności jest osobowy wymiar istoty ludzkiej (Skrzeszewski, 1994, s. 520).

W relacjach między samorządem - państwem - społecznością lokalną szczególnie istotną rolę, uzupełniającą subsydiarność, odgrywa zasada solidarności. Nakazuje ona wykorzystanie w organizacji życia państwowego wszystkich więzi naturalnych, które łączą ludzi z tytułu warunków życia, jak i tych samych celów wspólnoty. Ze współdziałania tych zasad wynika konieczność pozostawienia przez państwo szerokiej wolności wewnętrznej społeczeństwu oraz konieczność czynnego współudziału w organizacji i koordynowaniu jego działalności tak, aby powstał jeden organizm, jeden porządek społeczny.

$\mathrm{Na}$ te dwie zasady zachodzi zasada sprawiedliwości - związek między podmiotami władzy i działanie dla wspólnego dobra. Sprawiedliwość obejmuje wszystkie podmioty od osoby, przez struktury pośrednie, po państwo. Dla skutecznego jej funkcjonowania potrzebna jest obecność państwa w takich obszarach rzeczywistości polityczno-społecznej, jak np. w spełnianiu funkcji redystrybucji dochodu narodowego, właściwej lokalizacji inwestycji służących wyrównywaniu poziomu życia pomiędzy regionami, czy jako gwaranta rzetelnego rozdziału dotacji i subwencji.

Realizacja tych zasad przez samorząd jest bardzo trudna. Łatwiej byłoby objąć całe życie społeczne jednym systemem scentralizowanej 
administracji, który sprowadziłby ludzi do roli pionków, spełniających posłusznie zarządzenia państwa. W procesie decentralizacji opartej na filozofii personalistycznej chodzi nie tylko o interes władzy, ale też o podniesienie kultury społecznej, nauczenie samodzielnego życia społecznego oraz samodzielnego rządzenia się i organizowania.

W dokumentach społecznych Kościoła podkreśla się, że koncepcja człowieka jako osoby ma podstawowe znaczenie dla życia społecznego. Błędna, niepełna antropologia osoby skutkuje również błędną koncepcją życia społecznego i politycznego. Dlatego katolicy odrzucają zarówno marksistowską, jak i liberalną koncepcję człowieka, społeczeństwa i państwa. Marksizm zakładał, że poprzez zniesienie własności prywatnej uda się osiągnąć stan komunizmu, w którym zbędne będzie państwo, a jego miejsce zajmie nieokreślony komunistyczny samorząd społeczny. W liberalizmie własność prywatna jest podstawą, ale i tu państwo musi zamierać lub jedynie zachowuje funkcję dozoru prawnego ochraniania bogatych.

Państwo według personalizmu jest formą substancjalną społeczności, a władza państwa jest duszą społeczności, która ją określa. Katolicy nie wyobrażają sobie społeczeństwa bez państwa. Państwo określa podstawowe zasady wszelkich dziedzin życia. W tej koncepcji najgłębiej jest uzasadniona konieczność upodmiotowienia zarówno jednostek, jak i grup społecznych. Przy tym też ma charakter socjalny, tzn. wspiera grupy i kategorie społeczne, które nie są w stanie iść o własnych siłach. Państwo chroni więc w praktyce wrodzoną godność każdej osoby i tym samym buduje sprawiedliwy ustrój personalistyczny. Jest to konsekwencją miłości i solidarności międzyludzkiej. Tylko takie państwo buduje personalistyczny, solidarny i sprawiedliwy ład społeczny. Personalizm społeczny nie jest indywidualizmem, lecz syntezą indywidualizmu z socjetyzmem. Osoba nie istnieje bez drugiej osoby, jako absolutna, izolowana jednostka nie ma sensu. Samorząd terytorialny wpisujący się w tę filozofię jest państwu i społeczeństwu autentycznie potrzebny.

\section{Dylematy dalszego rozwoju}

Na tle personalizmu samorząd wygląda dobrze. Rzeczywistość jednak bardzo odbiega od tego obrazu. W tym okresie przejściowym, w którym żyjemy, jest to efekt dominującego i żywiołowego liberalizmu, mającego jeszcze dużo pozostałości z systemu myślenia postmarksistowskiego (np. zostawił ateizm, materialistyczne rozumienie człowieka). 
W porównaniu z samorządem liberalizm jakby przenosił się z wyższych pięter budowli globalistycznej do niższych, zagrażając również życiu samorządowemu. Zdaniem Czesława Bartnika, w teorii samorządy sprzyjają wolności obywatelskiej. W Polsce, w wieku XIX i w pierwszej połowie XX wieku, były nawet namiastką naszej suwerenności. Względnie dobrze wychodziły w kontekście mocnych struktur religijnych i etycznych, jakimi były dla Anglików - anglikanizm, dla Niemców - protestantyzm, dla Rosji - prawosławie. Dla Polaków katolicyzm stanowił niekwestionowany miernik wolności i prawa. Niestety, ta podpora katolicka upadła w życiu publicznym po roku 1944. Państwo komunistyczne wręcz złamało ten kanon godności i uczciwości katolickiej Polaka. Co gorsza, po 1989 roku nadal czynią to samo postkomuniści, masoni, lobby filosemickie oraz „katolicy prywatni”. Dlatego nawet na terenie katolickiej Polski rozwinęła się społeczna i moralna „dżungla”, walka o władzę i pieniądze, duch egoistyczny. W tej sytuacji również samorządy cierpią na wyraźny brak odpowiednich ludzi, warunków kulturowych i skutecznego prawodawstwa. Dla samorządowych stanowisk i rad nie ma jednego spoiwa, pojęcie dobra wspólnego jest w naszych czasach niezrozumiałe, zależność od aferzystów i ignorantów społecznych zbyt duża (Bartnik, 2006, s. 11).

W sferze samorządowej powinien panować dialog i współpraca, ale zbyt często chodzi o własne partykularne cele, zyski, czy urządzenie się w życiu. Ze względu na skalę całego społeczeństwa, jak i regionalną, pragnę zwrócić uwagę na rozwijający się personalizm społeczny, który wzywa katolików do odpowiedzialności za rozwój wspólnot lokalnych. W katolickiej nauce społecznej wzywa się wiernych związanych z różnymi partiami politycznymi, ruchami społecznymi i stowarzyszeniami katolickimi, aby aktywnie przystąpili do pracy w samorządach. Potrzeby są ogromne - pisze Andrzej Sujka. Kościół oczekuje i wymaga, aby wierni, którzy zechcą podjąć to wyzwanie, znali i umieli stosować katolicką naukę społeczną, aby byli wyposażeni w solidną wiedzę samorządową i fachową. Wielu z nich takimi umiejętnościami dysponuje. Bo przecież od lat angażowali się na rzecz rodzin i młodzieży, pracy oświatowej, przygotowania liderów różnych wspólnot, rozwoju kultury życia codziennego, ochrony środowiska naturalnego i praw człowieka. Kościół w swoim zakresie jest również ekspertem w sprawach społecznych, człowieka, ale przede wszystkim świeccy katolicy mogą decydować o odnowie moralnej społeczności, w których żyją. W tej dziedzinie jest wiele do zrobienia i to na dwóch płaszczyznach: poprzez udział we władzach samorządo- 
wych lub podejmując współpracę z nowymi samorządami (Sujka, 1998, s. 23-24).

Przykładowo, w odniesieniu do stanowisk liderów samorządowych można by założyć, że wójt, burmistrz i prezydent reprezentujący katolicki punkt widzenia starałby się harmonizować swe prawa i obowiązki $\mathrm{z}$ dobrem państwa i wspólnoty $\mathrm{w}$ ramach prawa i etyki. Personalistyczny model władzy oparty jest na regulacji prawnej, na wolnych wyborach bez manipulacji, respektuje interesy społeczności i wypełnia prawa społeczne i administracyjne. Kieruje się etyką niezależnie od układów politycznych ze względu na godność osoby. Może to jest ta właściwa droga, aby Kościół wkraczając w różne dziedziny nauki swoje osiągnięcia i etykę wniósł do konkretnych sfer działania, żebyśmy nie byli skazani na kadłubowe poglądy liberałów i socjaldemokratów.

Samorząd terytorialny wysuwa dzisiaj program społeczny, zajmując się problematyką człowieka, społeczności lokalnej i kultury w znaczeniu materialnym, duchowym i cywilizacyjnym. Współcześnie, dziedziny te decydują o kształcie życia społecznego. Dlatego potrzebne jest jego rozwijanie także na bazie nowych prądów doktrynalnych, jak np. katolicka nauka społeczna i personalizm społeczny, a zarazem wyjście poza ideologie liberalną i socjaldemokratyczną, by promować idee i wiedzę humanistyczną i etyczną oraz by dokonywać korekt ewoluującego i dominującego liberalizmu. Wzory ustrojowe są bowiem wyznaczane nie tylko przez sytuacje historyczne, polityczne, ale także przez panujące systemy doktrynalne, filozoficzne, stan nauki, które formułują pod adresem narodu określone cele i zadania, a także przez Kościół. I chodzić tu winno o kompleksowe odczytanie i rozumienie, zwłaszcza bieżącej sytuacji, jak i przyszłości. Naukowa koncepcja samorządu terytorialnego powinna zająć się człowiekiem w aspekcie społecznym, jego sytuacją wciąż ulegającą zmianom. Chodzi o wypromowanie doktryny samorządu terytorialnego rozumianej jako obrony wciąż zagrożonej godności człowieka żyjącego w różnych ustrojach. Istotną ideą samorządu terytorialnego jest przekonanie, że jego ustrój powinien być zorganizowany w ten sposób, aby prowadził do upodmiotowienia społeczności lokalnych, przez dopuszczenie ich do współzarządzania i do odpowiedniego uczestnictwa we własności.

Należy formować postawy samorządowców w duchu personalizmu, a także zwalczać te, które wyrażają się w egoizmie, arogancji, stronniczości, chciwości, karierowiczostwie, poprzez kontrolę administracyjną, wymiar sprawiedliwości i samych obywateli. Dotychczas administracja 
samorządowa w dużym stopniu rządzi w sposób biurokratyczny, władczy, manipuluje obywatelami, traktując ich przedmiotowo. Zreformowane zarządzanie winno łączyć znaną zasadę praworządności ze służebnością, z interesami ludzi, z humanizmem. Takie postawy będą sytuować samorządowców jako rzeczników personalizmu, otwartego na program reform społecznych i dobrze zorientowanej interwencji państwa.

Polacy wciąż nie są zdecydowani, na jakiej podstawie doktrynalnej oprzeć dalszy swój rozwój. Jak powinno być określone miejsce obywatela w polityce? Polak nie jest przekonany, że powinien aktywnie wkroczyć do polityki zarówno lokalnej, jak i centralnej. Co więcej, najważniejsi politycy kraju mówią do młodzieży, żeby nie studiowała socjologii i politologii, a przecież nie dysponując wiedzą społeczno-polityczną młodzież ta, nawet najbardziej odpowiedzialna, już się dystansuje od polityki.

Wciąż przyglądamy się dwóm zdecydowanie odmiennym doktrynalnym rozwiązaniom dotyczącym miejsca człowieka w polityce, no i w samorządzie: neoliberalizmowi i personalizmowi (odrzucono marksizm). Należy w tym miejscu wyraźnie zdać sobie sprawę z profilów obu prądów ideowych, by właściwie - prawdziwie - wyznaczyć nasze, polskie cele rozwojowe. Będąca w opozycji PO-PSL optuje za liberalnym indywidualizmem, społeczeństwem jednostek rywalizujących, będących w stałym konflikcie, które oddało władzę na drodze kontraktu wyborczego politykom. Aktualnie przy władzy jest też wielki, oligarchiczny biznes. W efekcie żyjemy w ustroju, który przeżywa kryzysy: parlamentarny, rządowy (afery), biurokratyczny. Dlatego nie można zgodzić się z mało ambitnym hasłem opozycyjnych elit (PO, PSL, SLD), które demonstrują stanowisko „by było jak było”. Odmiennie personalizm. Traktuje człowieka podmiotowo. Oznacza to faktyczny podział władzy pomiędzy człowiekiem - osobą, decydującą o celach swego życia i suwerennym, sprawnym państwem, które ma władzę w zakresie pozyskiwania środków dla realizacji dobra wspólnego, tj. zapewniające rozwój człowieka. Państwo ma troszczyć się o tworzenie warunków dobrego życia dla całego społeczeństwa i dążyć do tego, aby porządek społeczny nie był osiągany tylko przez przymus prawny, administracyjny, ale przez równowagę z siłami społecznymi działającymi w samorządach, które najlepiej zdają sobie sprawę z dynamiki rzeczywistości, a zwłaszcza z konieczności stałego równoważenia dynamiki prywatnej przedsiębiorczości ze sprawnym państwem, samorządami i powszechnym, wzrastającym dobrobytem. Chodzi o to, by przodujące samorządy, wybitni samorządowcy podjęli akcję na rzecz promocji idei 
dobra wspólnego, pomocniczości, solidarności, sprawiedliwości, no i unitarności. By w sferze działań władczych w obszarze społeczno-gospodarczym wspólnoty lokalne kontrolowały nie tylko urzędników, ale i oligarchów, by krytykowały ich za egoizm, korupcję, wąski partykularyzm, niską moralność, cwaniactwo, by rozwinęły dyscyplinę duchową i materialną i rozwijały uniwersalne myślenie. Personalizm społeczny to klucz do odrodzenia naszego życia materialnego i duchowego.

\section{Bibliografia}

Bartnik C. S. (2000), Personalizm, Lublin.

Bartnik C. S. (2006), Szkice do systemu personalizmu, Lublin.

Flewelling R. T. (2004), Ku personalizmowi społecznemu. Misterium Człowieka, Lublin.

Kida J. (1997), Samorząd gminny i jego funkcje rozwojowe, Warszawa.

Kołodziejski K. (2019), Zmierzch Zachodu, „W Sieci”, nr 9.

Kryczka P. (2000), Samorządność gminna - uśpiony potencjat, w: Spoteczności lokalne w perspektywie integracji europejskiej, red. B. Woźniak, Koszalin.

Majka J. (1982), Chrześcijańska myśl społeczna, Filozofia społeczna, Warszawa.

Mazurek F. J. (2001), Godność osoby ludzkiej podstawa praw czlowieka, Lublin.

Piekara A. (2010), Jakość administracji w Polsce. Zarys wspótczesnej problematyki, Warszawa.

Regulski J. (2012), Rozwój samorządności w Polsce. Próba przewidywań, w: Wizja przyszłości Polski-studia i analizy, red. B. Gawlas, L. Kuźnicki, Warszawa.

Roszkowski W. (2019), Roztrzaskane lustro. Upadek cywilizacji zachodniej, Kraków.

Skorowski H. (1966), Moralność społeczna. Wybrane zagadnienia z etyki społecznej, gospodarczej i politycznej, Warszawa.

Sobczak J. (2011), Prawo do dobrej administracji. Standardy europejskie a rzeczywistość polska, w: Wielopodmiotowość samorzadności gminnej w Polsce, red. B. Nawrot, J. Pokładecki, Poznań.

Strzeszewski Cz. (1994), Katolicka nauka społeczna, Lublin.

Sujka A. (1998), Samorzad terytorialny. Realne obywatelstwo, Warszawa.

Wójcik S. (1999), Samorzą terytorialny w Polsce w XX w., Lublin.

Wójcik S. (2002), Dynamika i bariery w rozwoju spoleczności lokalnych i samorządu terytorialnego w Polsce, „Przegląd Politologiczny”, nr 1.

Wójcik S. (2013), Samorząd i państwo. Przyszłość i odpowiedzialność, Lublin.

Wójcik S. (2015), Personalizm polityczny. Zarys problematyki, Lublin.

Wójcik S. (2016), Funkcje samorząu terytorialnego, „Roczniki Nauk Społecznych KUL”, t. 8/44, nr 3 . 
Wójcik S. (2018a), Państwo w ujęciu personalizmu, w: Stosunki międzynarodowe w procesie zmian, red. A. Stelmach, T. R. Szymczyński, M. Walkowski, Poznań.

Wójcik S. (2018b), Polskie drogi personalizmu społeczno-politycznego, Lublin.

\section{Local government in the perspective of social personalism}

\section{Summary}

The article outlines a program for the improvement of local government drawing on the new doctrine of social personalism. Social personalism identifies new possibilities of reforming the system and the operations of both local government and personal attitudes. This is a new way to develop local communities which promotes humanistic ideas and knowledge as well as ethics, while trying to rectify the increasingly degenerating dominant current of liberalism.

Key words: human, state, local government, social personalism 
